\title{
Challenges for Critical Pedagogy: A Southern European Perspective
}

\author{
Carmel Borg \\ Peter Mayo \\ University of Malta
}

Like all regions of the world, Southern Europe and the larger Mediterranean area are under the sway of the phenomenon commonly referred to as globalization, a process that, strictly speaking, has always been a feature of the capitalist mode of production characterized by periodical economic reorganization and an ongoing quest for the exploration of new markets. In fact, it is more appropriate, in the present historical conjuncture, to use the phrase, "the intensification of globalization." This intensification is brought about through developments in the field of information technology. It is a period in which mobility occurs at different levels. There is the constant threat of the "flight of capital" in a scenario where the process of production is characterized by dispersal and cybernetic control. We also witness the mobility of workers within and beyond the region. People from the south move up north in search of new opportunities.

Migration is an important feature of the Euro-Mediterranean region. As underlined at the 1997 Civil Forum EuroMed (Fondazione Laboratorio Mediterraneo, 1997),

Immigration represents the emerging aspect, probably the most evident, of the wide process which characterizes more and more the whole planet-globalization. Migrations represent more than a phenomenon, a historical certainty that can be found today, though with different features, in all countries and, in particular, in the most [industrially] developed. Migration phenomena are becoming more and more important within the Mediterranean basin. (p. 551)

With Southern Europe witnessing mass scale immigration from North Africa, the Mediterranean plays an important role in this process, serving, in the view of many, as "a kind of Rio Grande" (Malabotta, 2002, p. 73).

As we have written elsewhere, it can be argued, with respect to the movement of people from the Southern Mediterranean to the Northern Mediterra-

Authors' Note: This contribution draws, with substantial revisions and developments, on Mayo (2001, 2004a, 2004b). Liberating Praxis. Paulo Freirés legacy for Radical Education and Politics. Peter Mayo. Copyright $\odot 2004$ by Peter Mayo. Reproduced with permission of Greenwood Publishing Group, Inc., Westport, CT.

Cultural Studies $\leftrightarrow$ Critical Methodologies, Volume 6 Number 1, 2006 143-154

DOI: $10.1177 / 1532708605282809$

(C) 2006 Sage Publications 
nean and beyond, that the specter of the violent colonial process the "old continent" initiated has come back with a vengeance to haunt it (Borg \& Mayo, $2002, \mathrm{p} .45)$. This process is facilitated by the economic requirements of highly industrialized countries with respect to certain types of labor and the consideration that these requirements cannot be satisfied by the internal labor market, despite the high levels of unemployment experienced within these countries (Apitzsch, 1995). This gives rise to the presence of "guest workers" who are often victims of terrible exploitative situations in terms of payment, conditions of work, and the precariousness of their existence within the borrowed context. This point was addressed by Paulo Freire, a key figure in critical pedagogy, to whom reference will be made throughout this piece in view of the fact that he represents a voice from the South that speaks to concerns of the South.

In Pedagogy of Hope, Freire (1994) refers to his work in Geneva when he came in contact, through meetings and projects, with guest workers from Italy, Spain, Portugal, Greece, Turkey, and Arab countries. These migrant guest workers enabled Freire, on his own admission, to begin to come "in contact with the harsh realities of one of the most serious traumas of the 'Third World in the First': the reality of the so-called guest workers ... and their experience of racial, class and sexual discrimination" (p. 122). Freire goes on to indicate the fear of the oppressor as one of the challenges to be faced in this context in view of the fact that the opportunity to work, irrespective of how exploitative the conditions are, becomes the primary concern. It is this concern that takes precedence over the concern for political mobilization to confront the exploitation induced by this process of mobility of labor power across national boundaries. This mobility involves, in most cases, a severance from one's roots, in view of the process of uneven levels of development that is a characteristic of the capitalist mode of production. Confronting the fear of oppression remains a key challenge here for progressive educators working with migrants; it is a key challenge for progressive educators working in the countries that many of these emigrants left.

Of course, the foregoing point applies to most regions in the world and not just the Mediterranean. What renders the whole process significant in the context of this region is, once again, the fact that the receiving countries are the same countries that once witnessed mass waves of emigration. These countries have experienced the shift from being exporters to importers of labor power. This is not the place to engage in a discussion concerning the way the prejudice and racism experienced by settlers from North Africa and elsewhere differs from that experienced in the past by emigrants from today's receiving Southern European countries in such places as the United States, Canada, Australia, and South America. Nevertheless, in combating xenophobia and racism in this context, one would do well to recall the plight of people from the receiving country when settling abroad or in a more industrially developed region of the same country (e.g., migrants from Italy's Mezzogiorno region settling in the country's North). 
The architectural and demographic landscapes of Southern European cities are undergoing significant changes. Against this scenario, we are witnessing the transformation of Southern European cities. Whereas the population in these cities increasingly becomes cosmopolitan, the architecture is often a melange of the old coexisting with the new. The global exists alongside the local in a situation of hybridity. One can imagine, for example, Giotto's campanile being juxtaposed against McDonald's "twin golden arches." Furthermore, in certain Southern European cities and towns, the cupolas of churches that, for centuries, were perceived as bulwarks of Christendom against Islam, increasingly continue to coexist alongside minarets. ${ }^{1}$ This coexistence of architectural symbols of the different monotheistic religions, which have been the subject of much conflict in the past, is becoming an important feature of the skyline of some Southern European cities.

Within this cultural hybridity, one can easily encounter the tensions that have characterized the region for centuries. Xenophobia, or more accurately, islamophobia, has become widespread. In Nawal El Saadawi's (1997) words,

Perhaps the problem of the world has always been the "objectification," the nullification, of the "other." For the West or the North, the South is the other which exists only as an object to be exploited and oppressed. Christianity or Western culture sees Islam and Arab culture as the other. And in all religions, all that does not belong to God is seen as emanating from the devil. The problem of our world is to ignore, to dismiss, to destroy the other. To do this, the other must be satanised. (p. 137)

It can be argued that the historical roots for this form of racism can be found, among other things, in the anti-Islamic crusades that left their mark in several places in this region, becoming a feature of their so-called "cultural heritage." Cultures that, for centuries, had been constructed as being antagonistic are now expected to coexist within the same geographical space.

One of the great challenges for the educators, in this context, would be that of encouraging participants to cross their mental and cultural borders, to echo Henry Giroux's (1992) concept of border crossing. Crossing borders would, in this context, entail that critical educators step into the universe of representations with an attitude that transcends mere curiosity or lust for esoteric knowledge. Beyond the showcase knowledge, border crossing also means interrogating an assimilationist attitude toward the incoming Other, an attitude that negates the Self and reproduces dominant identities, rather than one that affirms diversity. Moreover, crossing borders implies the intersection of dominant schooling processes and the family cultures of migrant populations. Such intersections aim at demarginalizing these populations' cultural capital and worldviews that, at times, are drastically different from those of the educators. Border crossing problematizes the technicist approach to teaching. This approach skates over the issue of difference and acts as a carrier for reproductive discourses and ideologies. Border crossing is dynamic and, therefore, does not 
limit itself to a passive consumption of information about cultures. It is also flexible in curricular terms - a process, not merely a method, that is inclusive of different cultural expressions, including linguistic differences.

Perhaps the most important feature of a critical and antiracist approach to education, in this context, is that of developing a process of learning based on authentic dialogue, a key concept in the Freirean pedagogical approach, which is regarded as the means to

- permit the different cultures that make up our societies to become an integral feature of the educational process.

- allow participants to listen to others; "listening" is here being used in the sense conveyed by Paulo Freire in Pedagogy of Freedom, where it was argued that "listening" is to be distinguished from simply "hearing" and implies one's being "open to the word of the other, to the gesture of the other, to the differences of the other without being reduced to the other" (Freire, 1998, p. 107).

The nomadic existence that characterizes the continued movement of millions of people challenges the Mediterranean school. Often, schools fail to come to terms with the harsh existence experienced outside their perimeter; the educational institution overlooks the skills required for anyone to live successfully and chronically in transit. Confronted by an insensitive context, the "nomadic" Other is forced to assimilate the school culture rather than actively participate in its reinvention. Within this formula, the parent often becomes a coplayer in resisting the school, whereas teachers are not always willing to participate in emancipatory projects. Support, coordination, and time for reflection are often lacking. Interculturalism does not feature strongly in the formation of prospective teachers and in continuous professional development programs.

The Mediterranean school is still trying to come to terms with centuries of negation and assimilation policies and practices. Efforts are sporadic and disorganized. The net result is ghettoization and exclusion rather than inclusion. Rejection often dominates relations between the established community and its transient counterpart. Community conflicts, accentuated by poor economic performance and unemployment, are played out at school; stereotypes and prejudices are replayed within the educational institution.

The Euro-Mediterranean school is also plagued by structural realities. In an article that deals with the Euro-Arab dialogue, Aziz Hasbi (2003) refers to a duality that is multidimensional in nature, one that deeply affects the learner's attitude toward the Other:

The choice lies between education for the masses, which is hamstrung by budget shortfalls, and an elitist, Western style education accessible only to the minority who have the means to pay for private education or to leave the country and be educated abroad. The situation is sometimes complicated by the relocation of Western training, cutting off contact with local realities and reinforcing the impression that local education is bankrupt. (pp. 380-391) 
In this case, educational provision intersects with social class to severely curtail cultural dialogue. Material alienation is regarded by Ali Arayici (2003) as a serious impediment to dialogue:

Unfortunately, first generation immigrants residing in Europe are almost always unreceptive to the host culture. As traditionalists, their main goal is to earn money so as to buy land or a house in their country of origin, and they do not always see the need for cohabitation and integration in the foreign country where they live and work. (p. 453)

Cultural and social isolation, symptomatic of traditional family patterns, tend to prevent girls and women from accessing sites of cultural dialogue. Writing in the context of runaway Turkish children in Western Europe, Gunduz Vassaf (cited in Arayici, 2003) explains that children who are least likely to run away are often children of closed families who live in splendid isolation, away from school and other cultural sites.

Cultural dialogue thrives in a healthy intellectual environment (see the last section in Sultana et al., 1997). The Euro-Mediterranean school is often operating in a context that is intellectually arid. Abdeljalil Akkari (2003) provides us with an insight into this issue:

In contrast, the present situation is marked by a reluctance on the part of European researchers to work in the Arab world. The rapid rise in unemployment and scarcity of work among Arab academics trained in the region and the low level of return on the part of those educated in Europe are also signs unlikely to foster dialogue. (p. 400)

The various situations of conflict that characterize this region and that can cause tension in multiethnic societies render it indispensable to crossing borders in a variety of ways. Hasbi (2003) advocates a "pragmatic dialogue," one that is sufficiently "realistic and feasible." He stresses that dialogue "must avoid the traps of mindless moralizing. And it must banish the mutually distrustful mediaeval attitudes shaped by the geography of barbarity and/or unbelief of or towards a civilization or religion that believes itself to be superior" (p. 378).

Many of the Southern European regions have traditionally been steeped in the Christian religion, mainly Catholic and also Greek Orthodox. In a truly multiethnic environment, it is imperative that knowledge of the different religions is provided in various sites of learning, including those regarded by Henry Giroux as sites of "public pedagogy" (Giroux, 1999, 2001). There is always the danger, however, that one provides or constructs a caricature that, besides distorting reality, dehumanizes those being portrayed. The complexity of the situation can easily be ignored, with the religions being represented in simplistic terms (Fondazione Laboratorio Mediterraneo, 1997, p. 51).

The study of different religions should therefore be approached with the utmost seriousness and best preparation possible, with special emphasis being 
placed on the critical educator doing justice to the different religions involved. This applies to critical education carried out in different sites including courses for those involved in the mass media. In the case of the last mentioned, this would be in keeping with the recommendations of the 1997 Civil Forum EuroMed: "Mass media are invited to present a correct image of religions or cultures resorting, where suitable, to experts on the matter" (Fondazione Laboratorio Mediterraneo, 1997, p. 512).

Misconceptions with regard to Islam abound in the Western world. Countries of Southern Europe, which are recipients of immigrants from Arab countries, are no exception. For greater conviviality and dialogue to occur between people of different ethnic backgrounds with different cultural and related knowledge traditions, an effort must be made to learn about others, to cross the boundaries of one's social location, and to obtain the understanding and knowledge necessary to be able to engage in a critical reading of widely diffused texts (media images, news packages, representations in film and documentary) - reading the construction of the world through the word, if we are allowed liberties with Freire's famous phrase. ${ }^{2}$ This is necessary for one to be able to confront and problematize (this entails a problem-posing approach) the politics of misrepresentation that results from historically entrenched prejudices and deep-seated antagonistic dispositions. One would do well, in this context, to keep in mind Freire's emphasis on the rigors of a problem-posing dialogical approach to education and the need for educators to guard against the danger and insidiousness of a laissez faire pedagogy.

In many countries of Southern Europe, we are confronted by a Eurocentric cultural heritage that reflects a colonial past, especially in former centers of colonial power such as Spain and Portugal, and a past marked by crusades against the Ottoman Empire. A critical approach to education in the Southern European regions would enable its participants to engage critically with the region's or country's much acclaimed cultural heritage (culture not being used in the anthropological sense) and its politics of representation. Exotic and often demonic (mis)representations of alterity abound throughout this cultural heritage, alterity historically having been ascribed, in these areas, to a variety of people, including the Saracen, who is regarded as the Other in the context of 'Christian Europe'. The Other becomes the subject of a particular kind of construction, a form of Orientalism according to Edward Said (1978). This construction denotes a sense of positional superiority, on the part of those who promote this particular conception of the Other. It is a demonization reminiscent of the French colonial construction, "taught in the universities for over twenty years" and based on so-called "scientific proof" (Fanon, 1963, p. 296), of the colonized in Algeria, and North Africa in general. Frantz Fanon (1963) forcefully exposed this thesis in his classic anticolonial volume, The Wretched of the Earth.

A Freirean approach to education in this region would entail a pedagogy that engages critically with the politics of representation underlying different fea- 
tures of the artistic and historical heritage of the various countries in the South European region. A similar politics of representation characterizes the realm of popular culture in Southern European countries, with the Sicilian marionette shows, involving Crusaders and Predator (often the Saracen Other), being a case in point. In introducing immigrants to popular culture traditions in the receiving country, one ought to be wary of and highlight the contradictions found within these traditions; for it is precisely these contradictions that often contain stereotypical elements that denigrate significant cultural aspects of immigrants in Southern Europe.

Furthermore, in challenging such misrepresentations and misconceptions, critical educators in this region and elsewhere would do well to recognize and point out the important contributions that Arab, Islamic, and other nonEurocentric cultures have made toward the development of those aspects of science, medicine, mathematics, law, literature, theology, philosophy, architecture, learning (including the idea of the academy and the university), and other domains we have ethnocentrically come to associate with Western civilization (see Lê Thánh Khôi, 1999, 2000). Hasbi (2003) stresses this point when he asserts that

the knowledge and technologies which are the shared heritage of humanity were not created ex nihilo, but were built up in a lengthy process of accumulation to which every people has made its contribution. Efforts are now being made to give the West credit for a unique and absolute rationality and a creativity, which are seen as consubstantial with it. ... [This demonstrates] amnesia and ethnocentricity. (p. 378)

Civilizations are not to be presented in essentialist terms but should be viewed as being characterized by a strong degree of hybridity. Unfortunately, these contributions are excised from popular knowledge and common sense, the term being used here in the Gramscian sense, and we are often guilty, in our denigration of the culture of alterity, of what Mahmoud Salem Elsheikh (1999) calls the "debtor's syndrome" (p. 38).

Cultural productions, at the popular level and at the level of so-called "highbrow culture," can serve as codifications, in the sense intended by Freire. In conceiving of such productions as codifications, we as critical educators would enable ourselves and those with whom we are working to engage in a critical reading of our contemporary reality. In the process, we must keep in mind that concepts that form part of our common sense can partly have their roots in cultural and folklore traditions. They are concepts that have been accumulated over a long historical period, but not necessarily from a critically historical or political point of reference. This points to the need for using pedagogical activities that can help to critically unveil the important dimensions of immigrant students' cultures that can serve in the interest of their intellectual development and academic success. 
With this in mind, we should like to dwell very briefly on one form of cultural production that, in our view, has tremendous potential to serve as an educational tool that enables educators working with immigrants to empathize with their fellow humans who have arrived from other shores. Drama is the form of cultural production we have in mind. Drama has functioned as an important educational tool, including a community-learning tool, for many years. The work of Augusto Boal $(1982,1995)$ and other cultural workers in various parts of the world is well documented in the popular education and community studies literature and testifies to the effectiveness of theater as a pedagogical tool (see Cremona, 1997; Morgante, 2003). Theatre of the Oppressed (Boal, 1982) in the classroom has served as a vehicle for the process of codification and decodification in that it incorporates important features of a Freirean praxis, namely collective reflection, dialogue, and action in the formation of social consciousness. And although one must be wary not to make a fetish out of this process, drama can create powerful pedagogical experiences that foster greater interethnic solidarity and understanding across cultural differences.

One of us found quite instructive, in this regard, a dramatic representation to which participants at a 1998 conference on education in the Mediterranean held in Sestri Levante, Liguria, Italy, were exposed (Mayo, 1999). It was carried out by a troupe of players from Genoa and involved a juxtaposition of situations concerning the harsh realities of migration, both past and present. The plight of Italians migrating to the United States, Argentina, and elsewhere, and of Italians from the South moving into the country's Northern regions, was juxtaposed against that of Africans (including Arabs) and Eastern Europeans, with their personal narratives, moving into Italy. The scenes were poignant and quite revealing, based on a dialectical movement between past (a kind of "redemptive remembrance") and present (see the last chapter in Simon, 1992) in the hope of a transformed and healthy multiethnic democracy. As critical educators, we must work to construct daily experiences of personal meaning and collective democratic participation in the teaching of immigrant students, through the use of a variety of pedagogical approaches that mirror the effectiveness of drama in the classroom.

Undoubtedly, critical educators in the Southern European region face many challenges in their efforts to develop a strong democratic citizenship in the multiethnic context of schooling. With this in mind, we conclude this article by articulating the following suggestions in the teaching of immigrant students.

- Incoming migrant groups should not be regarded as harboring "deficits"; the programs and experiences provided should be those in which the members of all ethnic groups involved, including the ethnic groups to which the educators belong, are conceived of as subjects and not as objects of their learning.

- Educational policy makers should avoid establishing programs that smack of what the Italians call assistenzialismo (a term frequently used by Freire that is often given a literal translation in the English language texts) that often results in a form of "learned helplessness." 
- Critical educators should be wary of misrepresenting and "Otherizing" immigrant students as part of the hegemonic Western discourse.

- Critical educators require a good understanding of political economy (Darder, 2002; Gelpi, 2002; Walters, Borg, Mayo, \& Foley, 2004) and knowledge of how the economic system segregates along ethnic and national lines.

- Critical educators must become border crossers (Giroux, 1992) so that they can begin to understand something about the culture of others, including their religions.

- Critical educators in receiving countries need to recognize the contribution of others to the development of their own culture; this would include recognition of the contribution of non-European cultures to the development of aspects of what is termed Western civilization.

- The pedagogical approach should be one based on the key principles of liberatory education found in the work of Freire $(1970,1973,1994,1998)$ and other theorists (e.g., Apple, 1993, 1996; Buber, cited in Cohen, 1983; Darder, 1991, 2002; Giroux, 2000, 2001; hooks, 1994; McLaren, 1995, 2000; Morrow \& Torres, 2002; Shor, 1992), particularly with respect to the concept of dialogue that entails listening, rather than merely hearing.

- Critical educators must recognize that being a migrant represents only one aspect of a person's multiple and shifting subjectivities and the culture of origin intersects with a variety of other cultures that emerge from other aspects of the person's identity, namely a multiculturalism that incorporates gender, class, race/ethnicity, sexuality, age, and religion. $^{3}$

- A critical education should be based on the recognition that, although the work factor weighs heavily on the minds of those who migrate, the notion of citizenship ascribed to them should not be a two-dimensional one, that of producer and consumer, but one whereby they are conceived of as social actors (Martin, 2001) in a multicultural democracy.

- Drawing on Freire’s work as education secretary in São Paulo (Freire, 1993; O'Cadiz, Wong, \& Torres, 1998; Saul, 1995; Torres, 1994), schools should not remain isolated from the rest of the community but should be an integral part of the community and the surrounding contexts, as conceived by all its multiethnic, multicultural, and biodiverse features.

- In light of the preceding point, schools should be constructed as multipurpose community learning sites with implications for curricula (covering conventional hours and after-hours programs), administration, teacher/adult educator formation, and school architecture; migrants and other groups within the community should be able to feel a sense of ownership of and belonging with respect to the school that would appeal to their children's and their own frameworks of relevance, both during conventional school hours and after school hours, where physical adjustments need to be made for the creation of spaces that accommodate adults from the community.

Although this is not an exhaustive list, it is intended to stimulate necessary dialogue among critical educators who struggle to create educational conditions within Southern European schools conducive to the emancipatory needs of an expanding immigrant student population. Such dialogue is particularly necessary in these times of intensified economic globalization and the unprecedented movement of south of the equator populations to the north. 


\section{Notes}

1. The coexistence of Christian churches and minarets has been a feature of several places in the Mediterranean for centuries, in view of the fact that minarets dating back to the time of the Moors have been serving as bell towers for catholic churches in certain Mediterranean cities. The Cathedral at Valencia provides one example.

2. See Paulo Freire and Donaldo Macedo's (1987) Literacy: Reading the Word and the World.

3. The term multiculturalism, as we use it, is meant to capture the various cultures that characterize peoples' identities and societies in general and should not be used, as seems to be the case in many parts of Europe, interchangeably with multiethnicity.

\section{References}

Akkari, A. (2003). What is education's role? Prospects, 33(4), 397-403.

Apitzsch, U. (1995). Razzismo ed Atteggiamenti Verso gli Immigrati Stranieri. Il Caso della Repubblica Federale Tedesca [Racism and attitudes toward foreign immigrants]. Quaderni dei Nuovi Annali, 33, 67-76.

Apple, M. W. (1993). Official knowledge. Democratic education in a conservative age. New York: Routledge.

Apple, M. W. (1996). Cultural politics and education. New York and London: Teachers College Press.

Arayici, A. (2003). The problems of immigrant children in Europe. The case of the Turks. Prospects, 33(4), 453-466.

Boal, A. (1982). Theatre of the oppressed. New York: Routledge.

Boal, A. (1995). The rainbow of desire. London: Routledge.

Borg, C., \& Mayo, P. (2002). Towards an anti-racist agenda in education. The case of Malta. World Studies in Education, 2(2), 47-64.

Cremona, V. A. (1997). Creating community theatre. In G. Baldacchino \& P. Mayo (Eds.), Beyond schooling. Adult education in Malta (pp. 213-228). Msida, Malta: Mireva.

Cohen, A. (1983). The educational philosophy of Martin Buber. Rutherford, NJ: Fairleigh Dickinson Press.

Darder, A. (1991). Culture and power in the classroom. Westport, CT: Bergin \& Garvey.

Darder, A. (2002). Reinventing Paulo Freire: A pedagogy of love. Boulder, CO: Westview.

El-Saadawi, N. (1997). The Nawal El-Saadawi reader. London: Zed Books.

Elsheikh, M. S. (1999). Le omissioni della cultural Italiana. In I. Siggillino (Ed.), L'Islam Nella Scuola (pp. 30-45). Milan: Editore Franco Angeli.

Fanon, F. (1963). The wretched of the earth. New York: Grove Press.

Fondazione Laboratorio Mediterraneo. (Ed.). (1997). Obiettivi e Mezzi per il parternariato Euromediterraneo. Il Forum Civile EuroMed [Objectives and means for the EuroMediterranean Partnership. The Civil Forum EuroMed]. Naples: Magma.

Freire, P. (1970). Pedagogy of the oppressed. New York: Seabury.

Freire, P. (1973). Education for critical consciousness. New York: Continuum. 
Freire, P. (1993). Pedagogy of the city. New York: Continuum.

Freire, P. (1994). Pedagogy of hope. New York: Continuum.

Freire, P. (1998). Pedagogy of freedom: Ethics, democracy and civic courage. Lanham, MD: Rowman \& Littlefield.

Freire, P., \& Macedo, D. (1987). Literacy: Reading the word and the world. South Hadley, MA: Bergin \& Garvey.

Gelpi, E. (2002). Lavoro Futuro. La Formazione come Progetto Politico [Future work. Vocational education as a political project]. Milan: Edizioni Angelo Guerini e Associati SpA.

Giroux, H. (1992). Border crossings, cultural workers and the politics of education. New York: Routledge.

Giroux, H. (1999). The mouse that roared. Disney and the end of innocence. Lanham, MD: Rowman \& Littlefield.

Giroux, H. (2000). Stealing innocence. Corporate culture's war on children. New York: Palgrave.

Giroux, H. (2001). Public spaces/private lives. Beyond the culture of cynicism. Lanham, MD: Rowman \& Littlefield.

Hasbi, A. (2003). Introduction to the open file. Prospects, 33(4), 375-384.

hooks, b. (1994). Teaching to transgress. New York: Routledge.

Lê Thánh Khôi. (1999). Educazione e Civilta. Le società di ieri [Education and civilization. Yesterday's society] (G. Pampanini, Trans.). Rome: Armando Editore.

Lê Thánh Khôi. (2000). Il Mediterraneo e il Dialogo fra le Civilta [The Mediterranean and the dialogue among civilizations]. In G. Pampanini (Ed.), Un Mare di Opportunita. Cultura e Educazione nel Mediterraneo del Ill Millenio (pp. 49-60). Rome: Armando Editore.

Malabotta, M. R. (2002). Education for a multicultural Italy. Journal of Postcolonial Education, 1(2), 69-79.

Martin, I. (2001). Reconstituting the agora: Towards an alternative politics of lifelong learning. Concept, 2(1), 4-8.

Mayo, P. (1999). Towards a critical multiculturalism in the Mediterranean. Reflections on the conference: "Il Mare che Unisce. Scuola, Europa e Mediterraneo." Mediterranean Journal of Educational Studies, 4(1), 117-122.

Mayo, P. (2001). Globalisation, postcolonialism and identity. The role of education in the Mediterranean region. In N. S. Dokic (Ed.), Redefining cultural identities: The multicultural contexts of the Central European and Mediterranean regions (pp. 171-193). Zagreb: Institute for International Relations.

Mayo, P. (2004a). Adult education and multiethnic relations in the Mediterranean. In D. Caruana \& P. Mayo (Eds.), Perspectives on lifelong learning in the Mediterranean (pp. 2227). Bonn: IIZ-DVV.

Mayo, P. (2004b). Reinventing Freire in a Southern context: The Mediterranean. In Liberating praxis. Paulo Freire's legacy for radical education and politics (pp. 103-124). Westport, CT: Praeger.

McLaren, P. (1995). Critical pedagogy and predatory culture. New York: Routledge.

McLaren, P. (2000). Che Guevara, Paulo Freire and the pedagogy of revolution. Lanham, MD: Rowman \& Littlefield. 
Morgante, P. (2003). Percorsi di Formazione. Alteconomie [Routes of professional formation. Other economies]. In Un Nuovo Equilibrio Economico Nord-Sud (pp. 110-116). Rome: Palombi Editori.

Morrow, R. A., \& Torres, C. A. (2002). Reading Freire and Habermas. Critical pedagogy and transformative social change. New York: Teachers College Press.

O'Cadiz, P., Wong, P. L., \& Torres, C. A. (1998). Education and democracy. Paulo Freire, social movements and educational reform in São Paulo. Boulder, CO: Westview.

Said, E. (1978). Orientalism. New York: Random House.

Saul, A. M. (1995). Municipal educational policy in the City of São Paulo, Brazil (19881991). In C. A. Torres (Ed.), Education and social change in Latin America (pp. 155-162). Melbourne: James Nicholas Publishers.

Shor, I. (1992). Empowering education. Critical teaching for social change. Chicago: University of Chicago Press.

Simon, R. I. (1992). Teaching against the grain. Texts for a pedagogy of possibility. Toronto: OISE Press.

Sultana, R. G., et al. (1997). Insideloutside schools. Towards a critical sociology of education in Malta. San Gwann, Malta: Publishers Enterprises Group.

Torres, C. A. (1994). Paulo Freire as secretary of education in the municipality of São Paulo. Comparative Education Review, 38, 181-214.

Walters, S., Borg, C., Mayo, P., \& Foley, G. (2004). Economics, politics and adult education. In G. Foley (Ed.), Dimensions of adult learning. Adult education and training in a global era (pp. 137-152). Sydney: Allen \& Unwin.

Carmel Borg is the dean of the Faculty of Education, University of Malta. He works in the areas of critical pedagogy and curriculum studies, in which he has published widely. He is the editor of the Journal of Maltese Education Research. His books include Children and Youth at Risk. Narratives of Hope (coedited, Agenda, 2006) and Gramsci and Education (coedited, 2002). He has consulted locally and internationally in the area of curriculum.

Peter Mayo is an associate professor in the Department of Education Studies, Faculty of Education, University of Malta. He teaches in the areas of sociology of education and adult education in which he has published widely. His books include Liberating Praxis (Praeger, 2004), Gramsci, Freire and Adult Education (Zed Books, 1999, published in Catalan and Portuguese translation), Gramsci and Education (coedited, Rowman and Littlefield, 2002), and Beyond Schooling: Adult Education in Malta (coedited, Mireva, 1997). 